\title{
The Globalization of Sound and Identity: Korean Traditional Music in the World*
}

\author{
HeATHer A. Willoughby ${ }^{* *}$
}

A systematic preservation and promotion system of Korean cultural heritage was established through the Cultural Properties Protection Law. Since 1962, the government has promulgated Korean traditional music throughout the world for entertainment purposes as well as a form of soft power. However, although successful in terms of introducing music to a broader, global audience, the underlying intention of such performances was to build an internal sense of nationalism. This article briefly reviews the establishment of the CPPL, its correlation to nationalism and the ambition of wielding soft power through global performances of Korean traditional music. It further provides two examples of performances aimed at foreign audiences and offers suggestions for the increased effectiveness of future performances abroad.

Keywords: Globalization, Cultural Properties Protection Law, nationalism, soft power, Korean traditional music.

This work was supported by the Ewha Womans University Grant of 2004. Portions of this paper were presented at a conference entitled Korean Music in an Era of Globalization held at the Gyconggi [Kyŏnggi-do] Traditional Music Center, September 15, 2006. The author would like to thank those who read earlier versions of this paper, providing valuable insights and suggestions for further research.

** Assistant Professor at Ewha Womans University, Graduate School of International Studies, 11-1 Daehyun-dong, Scodaemun-gu, Seoul 120-750, Korea. Tel.: +82-2-3277-4457; Fax: +82-2-365-0942; E-mail: willoughby@ewha.ac.kr 


\section{I . INTRODUCTION}

I

t has been derisively stated that Korea is just a small peninsula, a shrimp among whales, but it is now readily apparent that despite its relatively small geographic size, the Republic of Korea (henceforth, Korea) has prospered at a remarkable rate within the last fifty years and now boasts a relatively healthy economy even in times of world financial difficulties. Amid the internal and external accolades of Korea's contemporary economic success is an equally well-entrenched pride in the nation's immense, deep and rich cultural heritage. Thus, while attempting to pursue economic gains, influence political arenas, and provide aid through various ODA initiatives, Korea-its government and general populace-has been equally concerned with demonstrating its value as a nation in terms of its traditional culture, and in turn, in wielding a degree of soft power by way of its cultural products.

A key component of Korea's traditional culture is its traditional music, both that of ancient origins and contemporary creations. This paper briefly reviews the establishment of the Cultural Properties Protection Law, including the designation of Intangible Human Properties and its correlation to nationalism and soft power, as well as addresses questions of how Korea's traditional music may be perceived by foreigners (or, more precisely, the current state of Korean music in the world) and a vision of or the future for Korean traditional music in a globalized world. In order to address these questions, it is imperative to first address the issue of globalization as it relates to culture, or more specifically music.

Discussions of globalization are not new, nor is the notion of soft power (as first coined by Joseph Nye in 2004); the state of the world today is obviously one of global interaction. There is no nation on earth that can prosper, or arguably even exist today, without at least some interaction with other nations and cultures. Globalization has been defined as an accelerated and intense interaction among nation-states-often aided or enhanced by technology-particularly in terms of economic, political, and military integration (cf. Friedman 2000; Haugerud 2005). Although as early as 1998, Frederick Buell defined globalization as the "ways in which nonlocal factors interact with local ones in producing sociocultural identities and forms" ( 549 , emphasis added), what is spoken of less frequently is the globalization of culture. Or, if addressed, the issue is often reactionary as it is steeped with a notion of protective nationalism. That is to say, when speaking of the globalization of culture, people are often only concerned with indigenous traditions being lost or absorbed into some nebulous vacuum of Western-imposed values. And thus, rather than willingly sharing the greatness of their cultural wealth, nation-states metaphorically bury their national treasures. Others, though wanting to share their cultural traits, are nonetheless wary of the possible negative affects of globalization. The charter 
of the [Korean] Cultural Heritage Administration, for example, warns that, "rapidly changing lives and the trend of globalization are operating as dangerous elements to gradually erode and destroy Intangible Cultural Heritage" (2006, 58, emphasis added).

What is of concern in this paper is the ways in which Korea is attempting to globalize, in positive ways, its traditional music, providing two specific examples as means of analyzing the current situation of Korean music in the world, after which a few suggestions are proposed that might be worth considering for the future expansion of Korean music propagation. Although extensive research has been conducted on this topic by the author, including interviews, review of programs and program notes, government statistics regarding performances abroad, etc., many of the examples discussed herein are based on personal experience, and thus are not intended to represent the success or failure of all performances aimed at foreign audiences. Additionally, much has been written in recent years about the so called "Korean Wave" in which, in particular, popular music, television shows, and movies have been exported to Asian and other nations. Nevertheless, this paper focuses on traditional music due primarily to the fact that the South Korean government as actively sought to preserve and promulgate the music.

\section{PRESERVATION, NATIONALISM, PROMULGATION AND SOFT POWER}

\section{Preservation}

The ideas of systematically preserving and promoting traditional arts in order to prevent them from the encroachment of a modern society began in the mid-nineteenth century. ${ }^{1}$ At that time, the music of the commoners, in particular, was (mistakenly) considered static; that is, something that was timeless and had remained the same for generations, but was on the verge of extinction due to industrialization. European composers of so-called art music (also known by the misnomer, "classical music"), including Bartok, Kodaly and Grieg, began dictating scores of folk songs, but it was not until the early twentieth century that Percy Grainger began recording folk songs in their natural environment using wax cylinders. ${ }^{2}$ It was at this same time that a growing sense of nationalism began to develop in Europe and elsewhere, igniting an interest not only in conserving indigenous arts but in promoting them as well. This phenomenon can most readily be seen in the advent of world exhibition fairs, which included stages for performances by North and South American Indians, Australian aborigines and Polynesians, among others.

In Korea, preservation of cultural artifacts began in earnest during the colonial 
period under the guise of the Chōsen hōmotsu koseki meishō tennenkinen-butsu hozonrei (Law for the Preservation of Natural Monuments, Places of Scenic Beauty and Historic Interest, and Treasures in Korea), enacted by the Japanese in 1933. This law was subsequently replaced by a much broader, Korean-sponsored preservation system concerned not only with tangible properties (yuhyŏng), such as buildings, pagodas, steles, and the like, but also intangible ones (mubyŏng), including arts and crafts, music and dance, and rituals and food, among others. Although there are points of similarity with the Japanese preservation system, the Korean legislation also included significant differences. "[T] he law was designed to strengthen Korean identity, by inference an identity undermined during the Japanese colonial period, weakened by the ravages of war and threatened by encroaching westernization... [It included] folk arts and crafts of the common people containing symbols of indigenous identity, rather than simply maintaining a focus on high culture where the artistic watermark may be apparent but where use had been restricted to the aristocracy and, often, where origins were in China" (Howard 2006, 6).

The 1962 national heritage law put in place by the Park Chung Hee [Pak Chŏnghŭi] administration (1961-1979) is entitled Munbwajae pobopŏp (Cultural Properties Protection Law, CPPL) and is still in force today. An important amendment was added to the law in 1970; in order to ensure that the intangible properties were not only preserved temporarily, but from generation to generation, the government began to appoint so-called "holders" (poyuja) of a given art. The holders (more commonly known as human cultural properties, in'gan munhwa$j a)^{3}$ are expected to provide regular performances or otherwise continue to create their arts and crafts and to teach apprentices (who themselves may later be designated as holders), for which they are entitled to a stipend and other forms of support. It is these artisans that were first sent abroad by the government, and form the genesis of a world-wide promotion of Korean arts, as will be addressed below.

\section{Nationalism}

As with preservation schemes in Europe a century earlier, the CPPL of Korea is steeped in notions of nationalism. Article 1 states that the law was to "seek the cultural progress of the nation and at the same time contribute to the development of the culture of mankind by preserving and utilizing cultural properties" (Office of Cultural Properties 1994, 37). Thus, not only was the preservation of the arts meant as a mode of progression for the nation based on its past artistic achievements, but that those arts were capable of aiding in the development of all of mankind; one can readily see the pride of the nation in a comment as bold as that. It should be noted, however, that arts and rituals associated with shamanism (the root of many performance traditions) 
or other superstitious folk traditions were considered unmeritorious and subsequently meant to be shunned.

According to ethnomusicologist and Korean cultural studies expert Roald Maliangkay, "[although], ironically, the CPPL was, in fact, strongly based on a Japanese precedent, these measures included banning all forms of expression that were reminiscent of Japanese culture or otherwise subversive, such as those mentioning, let alone favoring, communism or pacifism. And since shamanism was deemed a form of backward superstition that would stand in the way of modernisation [sic], shamanic rituals were stripped of any religious significance when performed in public" (2007, 53).

Further evidence of the nationalistic spirit of various preservation projects is found in the Cultural Heritage Charter published by the Cultural Heritage Administration. It reads, in part (emphasis added):

A nation's cultural heritage embodies its intellectual and spiritual contributions to the civilization of mankind.

Cultural heritage, whether tangible or intangible, represents both the essence and the basis of national culture.

Our Korean cultural heritage are [sic] even more dear to us because they have survived various unfortunate chapters of our long history.

Our ongoing efforts to understand, explore, and nurture this cultural heritage deepen our love of our country and of our fellow countrymen $\cdots$.

1. Cultural heritage must be preserved in their original form $\cdots$.

4. The value of our cultural heritage must be taught and widely propagated through education at home, in school, and in society.

5. All of us must contribute to preserving, developing, and transmitting our glorious national culture $(2006,3)$.

The nomenclature of the charter evinces nationalistic fervor, with a reminder of every citizen's duty to not only appreciate the greatness of Korean cultural heritage, but also to preserve and share the artifacts, rituals, performances, crafts, etc. There is an overt reference to the ability of the cultural heritage to represent the (supposed homogeneous) essence of the Korean people, followed by an oblique reference to the insidiousness of the Japanese occupation, among other national hardships, with the recognition that Korea, and its cultural heritage, have survived such tragedies, all of which should lead to a greater sense of love of the nation and one's countrymen.

It is apparent, that as much as the Park and subsequent administrations have wanted to promote and preserve the arts for the sake of the nation and the advancement of the broader world, they have also been extremely selective and controlling in terms of what were deemed "correct" arts that promoted the 
"right" kind of Korea. A tradition of designating particular types music and arts as being "correct" was inherent in the Confucian ideals that formed the foundation of the Chosŏn Dynasty (1392-1910); nevertheless, what is germane to this discussion are those genres that were considered important and representative of the nation as it existed in the 1960s. As indicated in the first mandate of the charter above, the government, or more precisely, the intangible cultural properties administrative body, comprised of scholars and government officials, often felt that there was one correct way to perform various artistic endeavors and they sought to preserve them as such.

Although at one level admirable in scope, this has caused significant problems within the art forms themselves. For example, in a number of traditional folk genres in Korea, improvisation was a key component in the past. Itinerant musicians would travel from town to town, sharing news and events from the capital or neighboring villages, and incorporate the names and deeds of important local figures into their performances. Through the process of preservation, however, many such genres have lost that vital quality of spontaneity, as it was determined that there was one correct way to perform, and that if one wants to be designated as a cultural property holder (Human Cultural Property), then one has to perform in the style-a near exact replication-of a preceding master teacher. What is ironic about this phenomenon, however, is that when it comes to international performances, there is often a total disregard of tradition, in the name of entertainment. Thus, even as Human Cultural Properties are sent abroad to demonstrate the rich heritage of Korean arts, there is at times a mandate (though perhaps unspoken and implied) to make sure the audience is dazzled by the "Sparkling Korea" (a motto of the Korean Tourism Organization), irrespective of the adherence to tradition.

\section{Promulgation of the Arts and Soft Power}

If Korean arts were to be used to aid in the development of the cultures of the world, then it was imperative that those arts were able to be seen not only in Korea, but worldwide. Some have suggested that the motivation for such performances were political as well as commercial. Kim Kwangok stated that the "tourism industry in the 1960s was based on the political motivation of promoting Korea's image abroad and the national economic strategy for the acquisition of foreign capital; it is only recently that the idea of tourism as a kind of cultural industry which should be based on the production and spread of art, folklore and traditional customs as gained support" (Korean National Commission for UNESCO 1995, 58).

Kim indicates that Korea was consciously seeking commercial gain as well as a degree of soft power when staging performance of traditional arts abroad. Maliangkay, however, counters this argument when he states: 
Kim seems to suggest that the idea of staging Korean culture abroad in order to generate soft power existed from the outset [i.e. 1960s]. That implies that tourism was at first seen as a more politically useful tool and only later as a more commercial industry. But how big a tool could it be? Korea has never been a popular tourist destination, perhaps because as potential travel destinations Japan and China have always been much better known in the West $\cdots$. It is implausible, therefore, that the promotion of Korean culture abroad was ever a form of commercial marketing primarily aimed at foreigners. It is more likely that tourism and cultural exchanges, now and then, also serve the administration's effort to promote nationalism domestically, as they fostered praise of Korean culture abroad. And if that's the case, then isn't it also possible that the importance of foreign praise somewhat outweighed the importance of wielding soft power in international relationships, and that even today, Korea's image abroad is of less importance than Koreans' image of themselves. ${ }^{4}$

It should be noted as well that although some commercial gain is possible, experience has shown that the majority of performances abroad, particularly from the 1960s to late 1980s, were sponsored almost exclusively by the Korean government, most often involving the intangible human properties and/or employees of the National Center for Korean Traditional Performing Arts or the Korean National Theater-both government-funded agencies. "The number of government-sponsored traditional music events staged abroad grew rapidly at least until 2001, from no more than 5 in the 1960s, to an average of 10 in the 1970 s and 1980s, to 36 in 1991, 42 in 1996, and 147 in 2001" (Maliangkay 2007, 54. Cf. Pak 1995, 374-378). Because such performances are government sponsored, great effort is made to invite local politicians and community leaders, local performers and artisans, as well as prominent Korean emigrants, all of who are provided with complimentary tickets. And, although recordings of the music performed may be sold after the event, there is little evidence that such exchanges significantly increase tourism among the audience members.

\section{TRADITIONAL MUSIC PERFORMANCES AIMED AT FOREIGN AUDIENCES}

As addressed above, the Korean government and other entities with a vested interest in preserving and promoting Korean cultural heritage have sponsored various rituals and performances abroad, as well as within Korea with a focus on foreign audiences. The following examples and corresponding hermeneutical 
observations are based on the author's own experience and thus are somewhat limited; nevertheless, they are instructive in that they can be used to elucidate the broader state of Korea's quest for soft power through the staging of traditional music performances.

\section{P'ansori Performances at Lincoln Center, New York, 2003}

\section{(1) The performance}

In the summer of 2003, the Lincoln Center (ostensibly the cornerstone of the musical world of New York City and perhaps even all of the United States) sponsored a five-day event featuring the performance of full-length versions of p'ansori tales. P'ansori, in brief, is a unique indigenous genre dating back to the $17^{\text {th }}$ century in which a solo performer relates a long, narrative story through song, dramatic speech and simple gestures, accompanied by a single drummer. Although at the height of the genre in the mid- to late-19 $19^{\text {th }}$ century the repertoire consisted of a larger number of tales, today, "traditional" p'ansori performances are comprised of only five stories. Thus, the series event held at the Lincoln Center presented one story each night by five of Korea's most well-known and well-respected performers, all of whom are Human Cultural Properties. 5

It was intriguing to witness the performance of a music so obviously foreign to the West-in terms of performance practice and tonal qualities ${ }^{6}$-but also to observe the audience and their responses to the performances. The theater seats approximately 600 people and although it was never filled to capacity, each night there was a sizable audience consisting of many Koreans and Korean-Americans, but also a large number of non-Koreans, many of whom had never heard p'ansori-or any Korean music, for that matter-before this event. Before and after the performances a number of these audience members were met with, both formally and informally, in order to get a sense of why they were there, what attracted them to the event, and what they gained from the performances. This event will serve as an example of the globalization of Korean music.

The performances themselves were "authentic" in the sense that the setting and props were as one would find at a traditional p'ansori performance in Korea. In other words, no attempt was made to make the performances more visually or aurally spectacular for a Western audience. (As mentioned before and will be discussed later, this is somewhat uncommon, as there is often a sense that in order to appeal to a foreign audience, only Korean music that is flashy, up-beat and visually stimulating can be presented). The only noticeable difference was the inclusion of a small screen above the stage to display English supertitles. No doubt most in the audience were well-accustomed to the extravagant musicals 
presented only a few blocks south in Times Square, but none displayed visible signs of being disturbed or bored by the relative simplicity of the p'ansori presentations. Of the interlocutors spoken with in-depth, two things stood out as paramount to their enjoyment of the performances: first, the musicians themselves and the supreme quality of their performances, and second, the emotional depth of the characters depicted in the stories. Several individuals commented that they had originally planned to only attend one performance, but were so intrigued by what they heard they decided to attend the remaining concerts-a significant investment in both time (each performance lasting $2 \frac{1}{2}-5 \frac{1}{2}$ hours, for a total of nearly 19 hours) and money (at least $\$ 50$ per ticket).

\section{(2) Lessons from the Lincoln Center performances}

By all indications, this display of Korean traditional music was an enormous success. ${ }^{7}$ Among the many positive reviews of the concerts, one New York Times' columnist (for whom, it appears, these concerts served as an introduction to the genre) described the first night's event by Kim Suyŏn as follows: "The texts elaborate on simple tales with flourishes and peregrinations that would do Mark Twain proud $\cdots$. The music begins in speech, rises to a chantlike recitative and often breaks into full-blown song. The style is hypnotic and captivating, though it takes time to attune the ear to a purposefully rough-hewn vocal timbre and the metabolism to a glacial pace." 8

It must be acknowledged that New York is a particularly culturally receptive city with sophisticated and knowledgeable audience members. Nevertheless, there are several important things that we can learn from this experience. First, whether or not an individual is familiar with Korean music, it is assumed that if they have some sense of aesthetic sensitivity, or have attended other performances of any variety, people can judge good quality when they see-or in this case, hear it. It is imperative, therefore, that if Korea wants to propagate traditional music to the rest of the world, thereby promoting its extensive cultural history, it must be willing to make great efforts to continue to train talented performers and then be willing to send them abroad-not only for brief performances in large countries such as the United States and major European nations, but for extended periods of time for workshops and classes, and to all or most nations of the earth.

Second, it can be concluded that Korean traditional music can be palatable, enjoyed, and understood by foreign audiences even in its "natural state." One might conclude that p'ansori, with its culturally-meaningful texts that are hard to understand even for native, well-educated Koreans, would be too difficult for foreign audiences to truly comprehend, but such is not the case. As mentioned above, a p'ansori performance-without flashy props or stimulating background music-can be appreciated by all audiences, whether or not they are familiar 
with this or other Korean genres. However, it must also be emphasized that it is important to ensure that the music-including an understanding of the text-is accessible to the audience. That means, in the case of p'ansori that the translations of the texts into English must be well done and be free of typos or other editorial errors; they must try to not only translate the basic story, but must also convey the humor and interpret the deeper meaning of the text-and this is not an easy task. The individual who is in charge of the subtitles during the performance must also be able to carefully monitor the performance to ensure that the proper text is being shown at the same time the performer is delivering the text. This, too, is an onerous task, seeing that most p'ansori performances include at least some amount of improvisation and interaction with the audience.

Again, many reviews written about the programs described above make specific mention of the supertitles, mentioning both the positive and negative aspects of the supertitles as well as the translation. One reviewer noted,

Supertitles are a two-edged sword. There is always some
loss of attention to the flow of performance when one is
having to shift focus up and down, but the stories required
understanding not only of the outlines but of the details
of the tales. The poetry and the humor were in the details...
My solution was to spend as little time as possible reading
the "translation," even at the expense of losing some of
poetic style and amazing, thesaurus-like elaboration of birds,
flowers, trees, animals, and forces of nature that punctuate
the travelogues and various listings.
Nevertheless, I couldn't help but pay closer attending to
the supertitles in the final pansori [sic]. They were both
advertently and inadvertently amusing. The translator evi-
dently was much influenced by Gilbert and Sullivan and
Alice in Wonderland as well as British slang. We find; "Oh
frabjous day, Calah, Calay," "beamish girl," "that is more
than sooth," and "mate." 9

As noted above, it is observable that audiences are willing to invest the time necessary to gain a deeper understanding of one particular genre. Often, for fear of boring an audience or thinking they will not be able to endure a typical lengthy performance of a single genre, Korean traditional musical performances abroad tend to only be "variety shows" (in which several genres are displayed for only 10-15 minutes), rather than focus on one genre. Although there are advantages to this approach-enabling an audience otherwise unfamiliar with Korea to experience a gamut of both elite and folk traditions-it cannot be assumed that non-Koreans are not interested or cannot comprehend the depth and breadth of Korean music. There is a tendency, to "dumb down" a performance to appeal 
to the lowest common denominator (in this case, the youngest or least interested audience member), when in reality, the majority of people will be more likely to be mentally and physically engaged in a performance if they know they are participating in a quality event. Provided, that is, they are given the tools to understand the music, text, cultural context, and meaning of a piece.

Finally, by focusing only on brief segments and highlights of a given musical tradition, concert organizers are ignoring one of the primary mandates of the Cultural Heritage Charter. Namely, that the music should be preserved, and it is thus assumed, performed in its original form. If then, it is the intent of government to provide performances for foreign audiences for continued nationalistic purposes and as a means of wielding soft power, then they must rethink the propensity to offer only (or primarily only) variety show performances, which, in reality display little of the "real" cultural heritage of the nation.

\section{World Music Festivals in Korea}

In recent years Korea has made some effort not only to propagate Korean music outside of its native homeland, but to invite foreigners within Korea to participate in events within the nation, as well as to invite foreign musicians to perform in Korea. More numerous and concerted efforts could be made in this regard, but nevertheless, the [Jeonju] Sori Festival (Chŏnju Segyae Sori Ch'ukjae) held every fall in Chŏnju serves as an example of what can be accomplished in this regard, as it specifically claims to be an international event (i.e. aimed at a foreign audience with foreign musicians).

Although having attended the festival for several years, the 2005 festival will be analyzed as the author was involved in various aspects of planning, performance, and critique of this event. According to the official website of the festival (www.sorifestival.com), the 2005 concert series included 431,000 festival attendees, including 2000 from overseas, plus 195 musicians from 25 countries. 10 The following chart lists all of the performances and events presented during the seven days of the festival (September 27-October 3), including the performers and their country of origin. ${ }^{11}$ 
TABle 1: 2005 Jeonju Sori Festival Program ${ }^{12}$

\begin{tabular}{|c|c|c|c|}
\hline Performance Title & Genre & Performer(s) & $\begin{array}{l}\text { Country } \\
\text { of Origin }\end{array}$ \\
\hline $\begin{array}{l}\text { Opening Performance-Confusion, } \\
\text { People and Harmony: Six } \\
\text { Portraits }\end{array}$ & $\begin{array}{l}\text { Korean tradition instrument } \\
\text { orchestra and Western } \\
\text { instruments and pansori } \\
\text { singer and a bass }\end{array}$ & Various & Korea \\
\hline $\begin{array}{l}\text { Great Master's Schools of Pansori } \\
\text { (Series 1) }\end{array}$ & Pansori & $\begin{array}{l}\text { Oh Jung-sook and } \\
\text { disciples }\end{array}$ & Korea \\
\hline $\begin{array}{l}\text { Great Master's Schools of Pansori } \\
\text { (Series 2) }\end{array}$ & Pansori & $\begin{array}{l}\text { Sung Chang-soon } \\
\text { and disciples }\end{array}$ & Korea \\
\hline $\begin{array}{l}\text { Great Master's Schools of Pansori } \\
\text { (Series 3) }\end{array}$ & Pansori & $\begin{array}{l}\text { Kim Il-goo and } \\
\text { disciples }\end{array}$ & Korea \\
\hline $\begin{array}{l}\text { Great Master's Schools of Pansori } \\
\text { (Series 4) }\end{array}$ & Pansori & $\begin{array}{l}\text { Cho Tong-dal and } \\
\text { disciples }\end{array}$ & Korea \\
\hline $\begin{array}{l}\text { Great Master's Schools of Pansori } \\
\text { (Series 5) }\end{array}$ & Pansori & $\begin{array}{l}\text { Park Song-hee and } \\
\text { disciples }\end{array}$ & Korea \\
\hline $\begin{array}{l}\text { Singing the Entire Five Pansori } \\
\text { (Series 1) }\end{array}$ & Pansori & Jang Moon-hee & Korea \\
\hline $\begin{array}{l}\text { Singing the Entire Five Pansori } \\
\text { (Series 2) }\end{array}$ & Pansori & Yoon Jin-chul & Korea \\
\hline $\begin{array}{l}\text { Singing the Entire Five Pansori } \\
\text { (Series 3) }\end{array}$ & Pansori & Song Jae-young & Korea \\
\hline $\begin{array}{l}\text { Singing the Entire Five Pansori } \\
\text { (Series 4) }\end{array}$ & Pansori & Yum Kyung-ae & Korea \\
\hline $\begin{array}{l}\text { Singing the Entire Five Pansori } \\
\text { (Series 5) }\end{array}$ & Pansori & Yu Soo-jung & Korea \\
\hline $\begin{array}{l}\text { Family Musical in Traditional } \\
\text { Tune: Hot Leaks and Spicy Briars }\end{array}$ & $\begin{array}{l}\text { Newly Created Pansori } \\
\text { Drama for Children }\end{array}$ & Various & Korea \\
\hline $\begin{array}{l}\text { Invited New Pansori: The Song } \\
\text { of Admiral Yi Sun-shin }\end{array}$ & Newly Created Pansori & Kim Young-ok & Korea \\
\hline $\begin{array}{l}\text { Young Artists' The First Eye on } \\
\text { Pansori: Cheeky Imagination }\end{array}$ & $\begin{array}{l}\text { New Created Pansori (for and } \\
\text { by Children) }\end{array}$ & Various & Korea \\
\hline $\begin{array}{l}\text { Young Artists' The Second Eye } \\
\text { on Pansori: A Tiger's Reprimand }\end{array}$ & New Created Pansori & Various & Korea \\
\hline $\begin{array}{l}\text { Young Artists' The Third Eye on } \\
\text { Pansori: Goguryo, A Great } \\
\text { Nation }\end{array}$ & Newly Created Pansori & Park Song-hwan & Korea \\
\hline $\begin{array}{l}\text { Old Phonograph Records and } \\
\text { Pansori Restored Series 1) }\end{array}$ & $\begin{array}{l}\text { Pansori (sung after the } \\
\text { manner of a founding member } \\
\text { of a particular style of pansori) }\end{array}$ & $\begin{array}{l}\text { Jung Hoi-seok sings } \\
\text { after Kim } \\
\text { Chang-ryong }\end{array}$ & Korea \\
\hline $\begin{array}{l}\text { Old Phonograph Records and } \\
\text { Pansori Restored Series 2) }\end{array}$ & Pansori & $\begin{array}{l}\text { Cho Young-je sings } \\
\text { after Lee Dong-baek }\end{array}$ & Korea \\
\hline
\end{tabular}




\begin{tabular}{|c|c|c|c|}
\hline $\begin{array}{l}\text { Old Phonograph Records and } \\
\text { Pansori Restored Series 3) }\end{array}$ & Pansori & $\begin{array}{l}\text { Song Jae-young } \\
\text { sings after Jung } \\
\text { Jung-ryul }\end{array}$ & Korea \\
\hline $\begin{array}{l}\text { Old Phonograph Records and } \\
\text { Pansori Restored Series 4) }\end{array}$ & Pansori & $\begin{array}{l}\text { Lee Jae-young sings } \\
\text { after Kim } \\
\text { Chang-hwan }\end{array}$ & Korea \\
\hline $\begin{array}{l}\text { Old Phonograph Records and } \\
\text { Pansori Restored Series 5) }\end{array}$ & Pansori & $\begin{array}{l}\text { Lee Gyu-ho sings } \\
\text { after Song Man-gap } \\
\text { and Chun } \\
\text { Myung-hee sings } \\
\text { after some great } \\
\text { female singers }\end{array}$ & Korea \\
\hline Pansori Animation & $\begin{array}{l}\text { Newly Created Pansori for } \\
\text { Children }\end{array}$ & Various & Korea \\
\hline $\begin{array}{l}\text { Traditional Music and Crossovers: } \\
\text { The Mural of Black Turtle (Series } \\
\text { 1: Strings) }\end{array}$ & $\begin{array}{l}\text { "Traditional tunes, images, } \\
\text { dance, yoga and martial arts" }\end{array}$ & Various & Korea \\
\hline $\begin{array}{l}\text { Traditional Music and Crossovers: } \\
\text { The Mural of Black Turtle (Series } \\
\text { 2: Dance) }\end{array}$ & $\begin{array}{l}\text { "Traditional tunes, images, } \\
\text { dance, yoga and martial arts" }\end{array}$ & Various & Korea \\
\hline $\begin{array}{l}\text { Traditional Music and Crossovers: } \\
\text { The Mural of Black Turtle (Series } \\
\text { 3: Drawings) }\end{array}$ & $\begin{array}{l}\text { "Traditional tunes, images, } \\
\text { dance, yoga and martial arts" }\end{array}$ & Various & Korea \\
\hline Film and Classical Music & $\begin{array}{l}\text { Experimental Popular Music } \\
\text { based on Western Classical } \\
\text { Music }\end{array}$ & $\begin{array}{l}\text { Various (Korean } \\
\text { Festival Ensemble) }\end{array}$ & Korea \\
\hline $\begin{array}{l}\text { Sori, Rejoice the Cheerful Rock } \\
\text { Concert }\end{array}$ & $\begin{array}{l}\text { "The most universal music } \\
\text { with the most Korean musical } \\
\text { asset" }\end{array}$ & $\begin{array}{l}\text { Various (including } \\
18 \text { well-known } \\
\text { popular singers and } \\
\text { group) }\end{array}$ & Korea \\
\hline $\begin{array}{l}\text { Sori, Going Together and } \\
\text { Enjoying Together }\end{array}$ & Crossover and Traditional & $\begin{array}{l}\text { Various (Orchestra } \\
\text { and Vocal Soloist) }\end{array}$ & Korea \\
\hline $\begin{array}{l}\text { Blowing Horn Looking at the Sky } \\
\text { (Series 1) }\end{array}$ & Crossover & $\begin{array}{l}\text { Various (Western } \\
\text { Classical Singer and } \\
\text { Orchestra) }\end{array}$ & Korea \\
\hline $\begin{array}{l}\text { Blowing Horn Looking at the Sky } \\
\text { (Series 2) }\end{array}$ & Crossover & \begin{tabular}{|l|} 
Various (Western \\
and Korean \\
Orchestras with \\
Popular and Korean \\
Traditional Singers)
\end{tabular} & Korea \\
\hline $\begin{array}{l}\text { Blowing Horn Looking at the Sky } \\
\text { (Series 3) }\end{array}$ & Crossover & Various & Korea \\
\hline $\begin{array}{l}\text { Invitation to Important } \\
\text { Intangible Cultural Properties of } \\
\text { Korea-Gut's Good (Series 1): } \\
\text { Gangnung Dano Festival }\end{array}$ & Traditional Shaman Ritual & Various & Korea \\
\hline
\end{tabular}




\begin{tabular}{|c|c|c|c|}
\hline $\begin{array}{l}\text { Invitation to Important } \\
\text { Intangible Cultural Properties of } \\
\text { Korea-Gut's Good (Series 2): } \\
\text { Gyunggi-do Dang Gut }\end{array}$ & Traditional Shaman Ritual & Various & Korea \\
\hline $\begin{array}{l}\text { Invitation to Important } \\
\text { Intangible Cultural Properties of } \\
\text { Korea-Gut's Good (Series 3): } \\
\text { Hahoe Byulsin Gut }\end{array}$ & Traditional Shaman Ritual & Various & Korea \\
\hline $\begin{array}{l}\text { Invitation to Important } \\
\text { Intangible Cultural Properties of } \\
\text { Korea-Gut's Good (Series 4): The } \\
\text { Jindo Sshitgim Gut }\end{array}$ & Traditional Shaman Ritual & Various & Korea \\
\hline $\begin{array}{l}\text { Invitation to Important } \\
\text { Intangible Cultural Properties of } \\
\text { Korea-Gut's Good (Series 5): } \\
\text { Bongsan Talchum }\end{array}$ & Traditional Mask Dance & Various & Korea \\
\hline $\begin{array}{l}\text { Invitation to Important } \\
\text { Intangible Cultural Properties of } \\
\text { Korea-Gut's Good (Series 6): } \\
\text { Namsadang Nori }\end{array}$ & $\begin{array}{l}\text { Variety Act (including } \\
\text { acrobatics and puppet show) }\end{array}$ & Various & Korea \\
\hline GioAria, a Popera Soprano & Popularized Classical & GioAria & Italy \\
\hline Wind from Asia & $\begin{array}{l}\text { Traditional and Newly } \\
\text { Composed Orchestral Pieces }\end{array}$ & $\begin{array}{l}\text { Various (with Jeonju } \\
\text { City Orchestra) }\end{array}$ & $\begin{array}{l}\text { Korea, } \\
\text { China, } \\
\text { Vietnam } \\
\text { and Japan }\end{array}$ \\
\hline Jazzchor Freiburg & Fusion Choir Music & Various & Germany \\
\hline $\begin{array}{l}\text { Yair Ensemble and Salame } \\
\text { Enscmble }\end{array}$ & Middle Eastern Traditional & Various & $\begin{array}{l}\text { Palestine } \\
\text { and Israel }\end{array}$ \\
\hline Musica Ataraxia & Free (Fusion) & Various & $\begin{array}{l}\text { China and } \\
\text { Korea }\end{array}$ \\
\hline Gamelan Asmaradana & Gamelan & Various & Indonesia \\
\hline Living Fire Ensemble & $\begin{array}{l}\text { Kurdish Folk/Contempory } \\
\text { Music Fusion }\end{array}$ & Various & Kurdistan \\
\hline Pre WOMAD Concert & Various & Various & Worldwide \\
\hline $\begin{array}{l}\text { Closing Ceremony: } 2005 \\
\text { Commotion! Communication? }\end{array}$ & Various and Pansori & $\begin{array}{l}\text { Various and An } \\
\text { Suksŏn (Festival } \\
\text { Organizer) }\end{array}$ & Korea \\
\hline
\end{tabular}

Of the 46 regularly scheduled performances planned for the 2005 Sori Festival, an overwhelming majority (38 of 46) consisted exclusively of Korean performers. Except a brief English language description of a given performance in the program manual, there were no other translations of story lines, lyrics or meaning/purpose of a performance provided in foreign languages. There were 8 performances by foreign musicians, three of which also included Korean performers. The greatest 
number of performances, 21 in total, was based on p'ansori-either traditional performances or newly composed pieces in the style of p'ansori. Although this percentage is high compared with other festival years, p'ansori does tend to be the predominant, featured genre, which is not surprising considering Chŏnju's geographical location in North Jeolla Province (the home, or at least heartland, of traditional p'ansori). Other Korean traditional performances included in the 2005 festival were shaman rituals, a mask dance, and the staging of traditional variety acts, games and music. Foreign-led performances included musicians from throughout the world, although a majority was from East Asian nations. Among these, there were both solo and group performances of traditional, classical and fusion arts.

The Sori Festival, with its objective of creating a stage for world music in Korea for both native and foreign audience members, is perhaps the most diverse and the most successful festival of its kind in Korea. The annual Hi Seoul Festival held each May in the capital also claims to invite famous foreign performers it stages, although perusing their schedules over the last several years it is apparent that the ratio of Korean to foreign performances is no more equal, and perhaps worse, than the festival in Chŏnju. What we can conclude, however, is that despite the valiant goals and efforts of the festival organizers, there is still a woeful showing of foreign musicians in Korea. Additionally, although the 2005 festival audience membership is said to have included 2000 foreigners, that is only .0046 of the total number of 431,000 participants! Obviously, far greater and more expansive foreign language advertizing and program explanations are needed to promote future events. The reason these statistics are problematic is because if Korea wants to be recognized as a global citizen willing to openly participate with the world, and more importantly to this paper, if Korea wants the world to recognize and appreciate its cultural heritage, it simply must do more to invite the world to Korea.

The two events described herein leads to a conclusion that Korean traditional music is enjoying a season of unprecedented exposure throughout the world and thus is being enjoyed by significantly more people than in the past. And that is probably an accurate conclusion. Nonetheless, sadly, much work is yet to be done before the average citizen of most counties is able to identify Korea on a map, let alone experience something of Korea's long and remarkable musical traditions.

\section{IMPROVED GLOBALIZATION OF KOREAN TRADITIONAL MUSIC}

How then can Korea better globalize its traditional music and cultural heritage? Many of the tactics that have been used in the past and present are productive 
and should continue to be pursued. However, there are also other things that should be considered, and new strategies that can be tried.

As indicated in the introduction, some nations seem to be unwilling in sharing their cultural heritage to the fullest extent for fear of it becoming polluted or diluted, misinterpreted or misused. But even Western composers such as Beethoven and Mozart have had their music adulterated in the form of synthesized renditions (such as in the 1970s series of "Classical Gas" recordings), unsuitable films, television commercials, and cartoons usage, or unorthodox looping for hip-hop performances. Mass appeal of music may not always generate the results one would expect or like, but to hide a treasured music from the public is equally unproductive. For example, many years ago a non-Korean New York rap singer used p'ansori in the background of several of his pieces. Certain self-proclaimed purists were offended by the seemingly inappropriate use of the music in a non-traditional context, but the performer and subsequently several individuals spoken to became exposed to and appreciative of the genre in a traditional sense because of the rapper's work. It is true that the more people that hear Korean music, the more it will be copied, imitated, appropriated into new contexts and settings. Whether or not the Cultural Heritage Administration and others want to admit it, culture and music have never been static, never pure; emic (inside) and etic (outside) influences are a part of every musical tradition and will continue to be so.

This is true not only of performances, but of teaching methodologies as well. Most Korean students of music have learned their art from a master teacher who follows a well-established form of pedagogy that has been passed down for generations. Learning strictly by rote, for example, is integral to many Korean musical practices. Such methods continue to be viable because they have obviously produced great masters for years. It is not being suggested that this time-tested pedagogy be abandoned all together, particularly for those Korean students wanting to pursue a career as a professional traditional performer. What is imperative outside of Korea, however, is a willingness to be more flexible when it comes to teaching foreigners. In learning to play various rhythmic patterns of samulnori (a genre for four percussion instruments) for instance, a student will often practice one single rhythm for hours exactly as their teacher demonstrated. This enables the student to not only master the sound and kinetics of the rhythm, but also teaches them to learn the profound subtly of performance. Few foreign students, unfortunately, have the same time to dedicate to that form of practice or the patience for it. They want to learn a whole song or performance now. This presents quite a problem-does one forgo the details and nuances of a performance in order to maintain the interest of the foreign student? Does one give up the tradition-the right or original way of doing things-to please the immediate needs of a new group of learners? As mentioned before, it is not prudent to abandon traditional methodology and pedagogy completely. 
But there are times that warrant flexibility in teaching styles, depending on the students and the purpose of the class. If one is teaching a student who is willing to dedicate years of time and effort in hopes of truly mastering an instrument or performance practice, then traditional methods are best. If on the other hand, one is teaching students for only a week, a month, or other limited period of time, then it is probably more important to allow the students to gain as much as possible and have as much fun a possible, at the expense of nuances and perfection.

Third, Koreans must not be overly concerned with "ownership" of their music. For instance, although samulnori is among the more widely performed genres of Korean music in the world, compared to Japanese taiko, it is less well-known and less favored. One reason for this phenomenon has to do with the management of professional Korean performances abroad. In general, most professional taiko groups will hire foreign public relations and management teams in a given country, while Korean groups tend to maintain only Korean-based organizations or firms for concert promotion. The Japanese method has several advantages, however. First, a local management company knows their audience-they know when people attend concerts, they know how much they are willing to pay, they know specific demographics of the audience and how to appeal to them in terms of advertising. They also have an interest in sustainability. That is, they do not only want to promote one concert a year, or every two or five years. They want to build an educated audience that will not only keep coming back, but will also bring their friends with them. This is accomplished by providing a regular series of concerts, by holding lectures and extended workshops, and by tapping into the resources available at local governments and institutes of higher learning. The point is, one should not be concerned only with providing occasional quality performances, but rather there should be an attempt to build a network of people-Korean and non-Korean alike-that are invested in the perpetual propagation of Korean traditional culture.

In conjunction, it is also imperative that there is a clear vision of what can be accomplished in the long-term and obtain the necessary funding to promote music not just for today, but for an extended period of time, in many countries. Funding has always been a formidable obstacle that is often outside the control of concert organizers and musicians, but it is obviously a key component to any worthwhile endeavor. In the U.S. and elsewhere it has been found that several Korean Studies programs in universities (even highly prestigious and wealthy schools) are being closed down because honorary positions and chairs sponsored by various Korean institutions were only funded for five years, with no plan of what would happen once the funding ended. The same is true of the promotion of Korean culture and music; one must have a long term plan and find the financial means to sustain our vision.

Finally, as mentioned above, one must ensure means are found to make Korean 
music accessible to others. One composer from Mexico stated that he has long been interested in Korean music and recently procured a grant that enabled him to visit the country in order to gain greater exposure to the instruments and music of Korea. Asked why some Korean music was appealing to foreign audiences, while others were not, he explained that certain musics had what he called "shared codes." 13 That is to say, persons of extremely diverse backgrounds can often relate to and understand music that is culturally different from their own indigenous heritage because there are certain sounds, patterns, physical and aural phenomena that are shared. While maintaining traditional performance practices and attempting to propagate and globalize Korean music then, one should be willing to make an investment into the learning of other world musics and seek for shared musical and visual codes that will enable one to truly globalize-not just spread Korean music abroad, but also welcome other world musics into Korea. If Korea wants to be heard on the stages of the world, Korea must provide a stage for the world here.

\section{CONCLUSION}

In conclusion, though much more needs to be said on this subject, there is little evidence that the Korean traditional music performances abroad or those performed domestically that are aimed at foreign audiences, are successful in wielding any profound or lasting sense of soft power. Although such performances, and to a greater extent, the Korean Wave, have generated interest in Korean culture and language, it has yet to be proven that there has been a significant increase in Korea's position in the world due to these events. Even such simple economic indicators as worldwide record (CDs, music downloads, etc.) sales of Korean traditional music show little increase in the last forty years despite the increased number of performance abroad. According to Joseph Nye, the mere fact that a given cultural good is consumed or enjoyed does not necessarily mean that the larger culture is being embraced or emulated. As he explains it, one may be fond of American junk food, but may not like the United States, and, in fact, those protesting American foreign policy may be donned in blue jeans and t-shirts (2004). Therefore, although the staging of Korean traditional music performances must be continued worldwide, and although efforts should consistently be made to introduce a greater, broader global audience to Korea cultural heritage, to do so with the hope of wielding any significant degree of soft power should likely be abandoned. 


\section{REFERENCES}

Buell, Frederick. 1998. Nationalist Postnationalism: Globalist Discourse in Contemporary American Culture. American Quarterly 50(3): 548-591.

Cultural Heritage Admistration. 2006. Important Intangible Cultural Heritage in Korea. Daejeon, Korea: Cultural Heritage Administration.

Haugerud, Angelique. 2005. Globalization and Thomas Friedman in Why America's Top Pundits are Wrong, eds. Catherine Besteman and Hugh Gusterson. Berkeley: University of California Press.

Friedman, Thomas. 2000. The Lexus and the Olive Tree: Understanding Globalization. New York: Anchor/Random House.

Howard, Keith. 2006. Perspectives on Korean Music, Volume 1 Preserving Korean Music: Intangible Cultural Properties as Icons of Identity. Aldershot, England: Ashgate Publishing Limited.

Jeonju Sori Festival. 2005. Main Catalogue-Jeonju Sori Festival 2005. Chŏnju: An Sook-seoun [An Suksŏn]/Jeonju Sori Festival Organizing Committee

Korean National Commission for UNESCO. 1995. The Cultural Industries: Social and Economic Implications in Final Report of the First Asia-Pacific Cultural Forum, ed. Korean National Commission for UNESCO. Seoul: Korean National Commission for UNESCO.

Lee, Bo-hyung [Yi Po-hyŏng]. 1990. Preserving Traditional Performing Arts. Koreana 4(2): 87-88.

Maliangkay, Roald. 2007. Staging Korean Traditional Performing Arts Abroad: Important Intangible Intercultural Performance Issues. Sunghyun Journal of East Asian Studies 7(2): 49-68.

Nye, Joseph. 2004. Soft Power: The Means to Success in World Politics. New York: PublicAffairs.

Office of Cultural Properties. 1994. The Preservation and Transmission System for The Intangible Cultural Properties of The Republic of Korea. Unpublished.

Pak, Sŏnghŭi. 1995. Haeoe mit nambuk ŭmak kyoryu 50 nyŭn. In Kwangbok 50 nyŭn kugak chunghŭng 50 nyŭn. A collection of papers presented at a forum organized by the National Center for Korean Traditional Performing Arts to celebrate 50 years of independence, held at the institute from 27 to 28 September. ed. the National Center for Korean Traditional Performing Arts. 


\section{ENDNOTES}

${ }^{1}$ The emphasis here is on systematic, often government sanctioned conservation of art, particularly music. It should be noted, however, that there are numerous examples of ancient texts in Europe, Asia and elsewhere documenting ritual and entertainment performances for the sake of replication and preservation.

2 See Chad Criswell. "Folk Music Preservation."

http://www.musicedmagic.com/music-history/folk-music-preservation.html (accessed October 3, 2009).

${ }^{3}$ A clarification of terminology is needed. The "jae' of munbwajae has often been translated as "Asset" (Cultural Asset), and subsequently in'gan munbwajae as "Human Cultural Asset." These terms seem to most closely match the intention of the preservation system. Alternatively, following the nomenclature of UNESCO, terms such as "Cultural Treasure" and "Living Human Treasure" have also been used. Nevertheless, contemporary convention and Korean documents now refer to the same terms as "Cultural Properties" and "Human Cultural Properties," thus, these are the terms I will henceforth use.

${ }^{4}$ See Roald Maliangkay. "The Myth of Soft Power: Selling Korean Pop Music Abroad." From the presentation proceedings of Berkeley's Institute for East Asian Studies, Catching the Wave: Connecting East Asian through Soft Power, October 5-6, 2007.

http://ieas.berkeley.edu:8002/events/pdf/2007.10.05-Maliangkay.pdf (accessed October 3, 2009).

'The performers and their status are as follows: Kim Suyŏn ('Apprentice' National Cultural Property in $P^{\prime}$ 'ansori); Cho T'ongdal (National Cultural Treasure in P'ansori); Kim Yŏngja (National Cultural Property in P'ansori); Kim Ilgu (National Cultural Property in P'ansori); and An Suksŏn (National Cultural Property in Kayagum Pyŏngch'ang-a genre related to p'ansori, in which the performer sings relatively brief songs from the longer $p$ 'ansori tales while accompanying herself on a 12-stringed zither. It should be noted, however, that An Suksŏn is also acknowledged as one of the greatest living p'ansori masters.)

${ }^{6}$ While using a large variety of vocal techniques and tone qualities, p'ansori tends to favor a raspy sound that can sound quite harsh to foreign (and sometimes even Korean) ears.

7 It should be noted, that after leaving New York, the same performers traveled to Scotland to participate in the 2003 Edinburgh Arts Festival, eliciting similar, favorable reviews.

"See James R. Oestreich. "Festival Review: From Korea, Simple Tales Elaborately Told." New York Times Online. July 19, 2003.

http://www.nytimes.com/2003/07/19/theater/festival-teview-from-korea-simple-tales-elaboratelytold-in-song.html?scp $=1 \&$ sq $=\% 22$ From + Korea $\% 2 \mathrm{C}+$ Simple + Tales $\% 22 \&$ st $=$ nyt

(accessed October 3, 2009).

"See Perry Bialor. "Pansori at Lincoln Center Festival 2003." The New York Theatre Wire.

http://www.nytheatre-wire.com/pb03074t.htm (accessed October 3, 2009).

${ }^{10}$ See Sori Festival History. http://www.sorifestival.com/english/2009/main-sub.html?mTop=A4000 (accessed October 5, 2009).

"Solo or prominent performers will be listed individually. However, in the case of lesser-known individuals or group performances, individuals will not be stated.

12 Although occasionally awkward, the original English language titles, as provided in the printed program notes will be retained. The chart represents performances associated with the festival proper, although a fringe festival and a few additional participatory activities/performances, particularly those aimed at children, were held simultaneously.

13 Arturo Salinas, Personal Communication, 2006. 